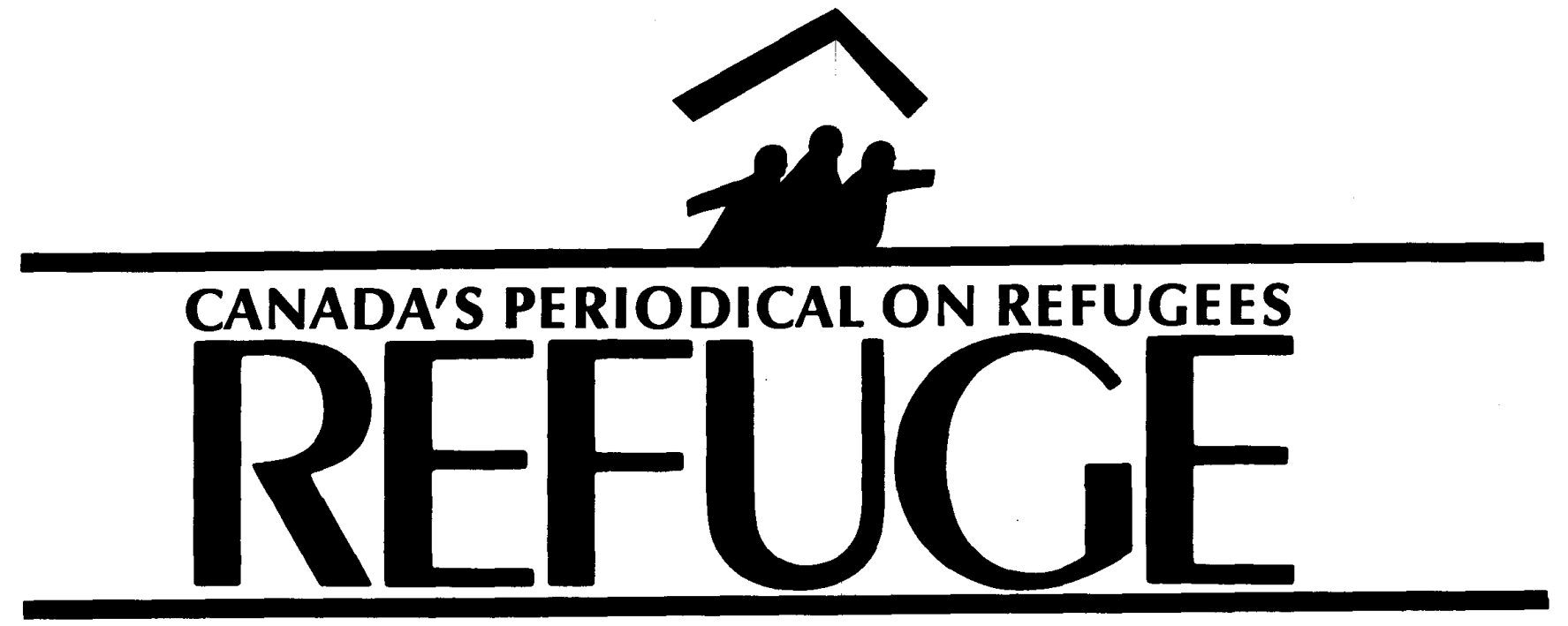

Vol. 9 , No. 1

SPECIAL Issue

October 1989

\title{
Afghan Refugees
}

When Duke University Professor and Afghan scholar Louis Dupree was asked a year ago to edit a special issue of Refuge on Afghanistan, he immediately set to to work on this project with the help of his wife, Nancy Hatch Dupree. The issue was beginning to take shape when Louis Dupree died of lung cancer in March of this year. Now that the project has been completed, we are dedicating the results to his memory.

\section{Louis Dupree: In Memoriam}

\author{
by Anders Fänge
}

There is a story about Louis Dupree. Once, in the early eighties, during a discussion about Afghanistan in the State Department, an expert on the Soviet Union said that the Afghans will lose this war because there has so far never been a case in history where the Soviets have left a country once they have put their hands on it. His argument was simple. The Soviet Union was a superpower with all its resources and the biggest war machine the world had ever seen; Afghanistan was a backward country, one of the poorest, with no army, a divided resistance, little organization, and so on. Louis was there and he objected. He told the man: "Perhaps you know the Soviet Union, but it is obvious that you don't know the Afghans. If you did, you would also know that they will not give up, that they'll go on fighting whatever the odds, they will continue to resist until the Soviets are forced out of their country."
He said the same thing on numerous lectures around the world, in articles and interviews, in every possible fora where he could make his voice heard. Even during the worst years, between 1984 and 1986, when the Soviets tried to bomb Afghanistan back to the Stone Age, when they attacked furiously in a last desperate attempt to crush the Afghan spirit of resistance, when many of us who supported and believed in the Afghan cause did not dare to hope any more; even then he never expressed a single doubt that the Afghan people would reach victory in the end.

Of course, there were a lot of people who said that Louis certainly knew a lot about Afghanistan, but his analysis emanated more from feelings than from facts. I was one of them, and I was wrong. Louis was right, because he had, above all,

\section{IN THIS ISSUE:}

Louis Dupree: A Tribute by $M$. Nazif Shahrani

Continued on page 2

The Canadian Response to Afghanistan by Jane Thomas

Aid in Afghanistan: Limitations and Possibilities by Anders Fänge

Problems and Prospects of Repatriation by Peter Rees

Prospects for Afgan Women After Repatriation by Nancy Hatch Dupree

Refugees and Intemational Relations reviewed by Lisa Gilad

From the Jews to the Tamils reviewed by Indhu Rajagopal

page 3

page 4

page 8

page 11

page 14

page 17

page 18 
one thing in common with the Afghans, which was crucial in his profound and unique understanding of them; just like them he was not a quitter. Just like the Afghans he was a fighter.

Now he has left us, attacked from within by that dreadful disease. But I refuse to believe that he gave up. I am convinced that he fought until that stage where no fights are possible any more, where you are left alone with your creator. He died the same way he had lived. He

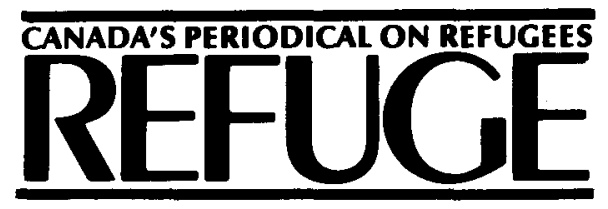

Centre for Refugee Studies, York University. Sulte 234, Administrative Studles Bullding. 4700 Keele Street, North York, Ontario, Canada M3J 1 P3. Telephone: (416) 736-5663. Fax: (416) 736-5687. Electronic Mall Via Bitnet Address: REFUGE@YORKVM1.

Guest Editor:

Nancy Hatch Dupree

Editor:

Howard Adelman

Executive Editor:

Alex Zisman

Illustrations:

Herminio Ordóñez

Circulation Manager:

Helen Gross

\section{Assistant to the Circulation Manager: Ching Man (C.M.) Wong}

Refuge is dedicated to the encouragement of assistance to refugees by providing a forum for sharing information and opinion on Canadian and international issues pertaining to refugees. It is published four times a year by the Centre for Refugee Studies. It is a non-profit, independent periodical supported by private donations and by subscriptions. It is a forum for discussion, and the views expressed do not necessarily reflect those of its funders or staff.

All materials in Refuge may be reproduced without permission unless copyrighted or otherwise indicated. Credit should be given to the author or source, if named.

Subscription rates for one year are $\$ 20.00$ in Canada and US $\$ 25.00$ overseas. Please enclose payment with your order.

Logo design:

Dreadnaught Co-operative Inc., Toronto

Layout: PAGES $p^{\mathrm{s}}$

Second Clase Mall Registration NP 5512 ISSN 0229113 came a long way. He saw the Soviets leaving, but he did not reach his own personal victory, which would have been to see his beloved Kabul once again. The Afghan people, and we who are working to help them, have lost one of our best friends and staunchest supporters. We will miss his deep knowledge and good advice, his stories and jokes, the spirit he created around him. But, above all, we will miss his straight-forward ness and honesty, his habit of calling things for what they are; because Louis Dupree never hesitated to call a cat a cat and a pig a pig, to the satisfaction of many and to the dismay of those who deserved it.

There are too few Louis Duprees in this world and now there is one less; the world is a poorer place.

Anders Fänge started as a reporter in Afghanistan in 1981. He has been the Director of the Swedish Committee for Afghanistan - one of the oldest and today the biggest crossborder humanitarian agency working in Afghanistan - since 1983. He was also one of the founders of the Agency Co-ordinating Body for Afghan Relief (ACBAR) and is now its Vice-Chairman.

\section{The Current Situation}

Most Members of the Citizens Commission on Afghan Refugees who visited Pakistan previously accepted the widely held view of governments and the general population that: "the regime in Kabul will probably fall soon after the Soviet withdrawal".

Obviously, the conventional wisdom was wrong and it now appears that the fighting will continue on for an indeterminate time that some speculate will last for years unless there is a negotiated settlement between the government in Kabul and the Interim Government based in Peshawar. Here it should be pointed out that one member of the Commission, Robert Cranborne, did not concur with this assumption. In an article in the Spectator (August 6, 1988), he points out that the Geneva accords provided an agreement for the Soviet withdrawal from Afghanistan, but did not contain provisions that would guarantee peace. He discusses the "fiendishly complicated political situation" and opines that the existing parties are not likely to become more effective and that the West should encourage the commanders "to take power into their own hands".

As a consequence of the continued fighting, substantial numbers of Afghan refugees, largely from the Jalalabad area, continue to flee to Pakistan. During my stay, the Prime Minister of Pakistan, Benazir Bhutto, announced that 800-1,000 new refugees are now arriving daily in Pakistan. Others have cited a figure of 70,000-75,000 new refugees since November 15, 1988. I visited one of the refugee camps for new arrivals, the Shindand Camp near Hangu. There were an estimated 8,000-10,000 refugees living in tents, under a glaring sun, on a wind- swept dusty plain. Many of the tents had been blown down by strong winds, and could not be reconstituted because of defective poles. Safe water and food had to be brought in by truck. The provision of basic health care was inadequate. I was told that ten children had died the previous day and was shown several fresh graves. Throughout my visit the refugee elders pleaded with me for additional help. An obvious point to be made is that programmes for refugees in Pakistan must not yet be de-escalated. To the contrary, additional support services are urgently required by the new arrivals.

The above comments have been excerpted from James C. Strickler's"Report of Visit (5/22-5/28/89) to Peshawar and Hangu Pakistan", dated June 16, 1989. The author is is a Member of the Citizens Commission on Afghan Refugees.

\section{Canadian Aid}

According to Government of Canada sources, about $\$ 300$ million has been provided to Afghan refugees between 1980 and 1988 through the United Nations and the Government of Pakistan. It is mostly in the form of food commodities. While this may sound like a lot of money, given the magnitude and duration of this refugee crisis, it is not. It works out to far less than one cent per day per refugee.

Government-to-government aid was also withdrawn in 1980 . That is still in effect. In 1988, however, Canada restored aid through NGOs to Afghanistan. Only about $\$ 2$ million has been provided (through NGOs) inside Afghanistan during the whole war thus far. 